\title{
Artesunate attenuates glioma proliferation, migration and invasion by affecting cellular mechanical properties
}

\author{
SHIZHONG LIAN $^{1 *}$, RUYI SHI ${ }^{2,3^{*}}$, XUN HUANG $^{4 *}$, XIAOLING HU $^{2,5^{*}}$, BIN SONG $^{2,6^{*}}$, \\ YINSHAN BAI $^{7 *}$, BIN YANG $^{2,8^{*}}$, JINYAO DONG $^{9 *}$, ZHIJIE DU $^{10}$, YANYAN ZHANG $^{9}$, \\ JUNMEI JIA ${ }^{6}$, NING MA ${ }^{1}$, GENG GUO ${ }^{1}$ and MINGYU WANG ${ }^{1}$ \\ ${ }^{1}$ Department of Neurosurgery, The First Hospital of Shanxi Medical University, Taiyuan, Shanxi 030001; \\ ${ }^{2}$ Key Laboratory of Cellular Physiology, Chinese Ministry of Education; ${ }^{3}$ Department of Cell Biology and Genetics, \\ Shanxi Medical University, Taiyuan, Shanxi 030001; ${ }^{4}$ Department of Materials Science and Engineering, Jinan University, \\ Guangzhou, Guangdong 510630; ${ }^{5}$ Department of Pharmacology, Shanxi Medical University, Taiyuan, Shanxi 030001; \\ ${ }^{6}$ Department of Oncology, The First Hospital of Shanxi Medical University, Taiyuan, Shanxi 030001; \\ ${ }^{7}$ Basic School of Guangzhou Medical University, Guangzhou, Guangdong 511436; \\ ${ }^{8}$ Department of Tumor Surgery, Shanxi Cancer Hospital, Taiyuan, Shanxi 030001; \\ ${ }^{9}$ Department of General Surgery, The First Hospital of Shanxi Medical University, Taiyuan, Shanxi 030001; \\ ${ }^{10}$ The Fourth People's Hospital of Linfen, Linfen, Shanxi 041000, P.R. China
}

Received January 25, 2016; Accepted March 7, 2016

DOI: $10.3892 /$ or.2016.4847

\begin{abstract}
Glioma is one of the most common malignant brain tumors. Current chemotherapy is far from providing satisfactory clinical outcomes for patients with glioma. More efficient drugs are urgently needed. Artesunate (ART) is clinically used as an anti-malarial agent and exhibits potent antiproliferative activity as a traditional Chinese medicine. In addition, ART has been shown to exert a profound cytotoxic effect on various tumor cell lines, presenting a novel candidate for cancer chemotherapy. However, its anticancer effect on glioma by altering cell biomechanical properties remains unclear. The present study aimed to identify the anticancer effects of ART on human glioma SHG44 cells by assessing cell proliferation, migration/invasion, the expression of claudin-1 and the biomechanical properties of ART-treated SHG44 cells. The proliferation of the SHG44 cells was assessed by MTT assay. The cell apoptosis was detected by flow cytometry. For cell migration and invasion assays, the Transwell was used. The expression of the gene claudin-1 was detected by polymerase chain reaction. The cell membrane and biomechanical properties, as targets of ART action, were investigated by atomic force
\end{abstract}

Correspondence to: Dr Ruyi Shi, Department of Cell Biology and Genetics, Shanxi Medical University, 56 Xin Jian Nan Road, Taiyuan, Shanxi 030001, P.R. China

E-mail: tomruyi@163.com

*Contributed equally

Key words: artesunate, glioma, gene claudin-1, biomechanical properties, antitumor effect microscopy (AFM). ART significantly inhibited the proliferation of SHG44 cells in a dose- and time-dependent manner. After treatment with $30 \mathrm{mg} / \mathrm{l}$ ART, the level of cell apoptosis was significantly increased (from $6.88 \pm 0.062$ to $23.7 \pm 4.16 \%$ ). Furthermore, the cell migration and invasion abilities of the SHG44 cells were markedly inhibited after treatment with $30 \mathrm{mg} / 1$ ART. Compared with the control group $(0 \mathrm{mg} / 1$ ART), the SHG44 cells treated with $30 \mathrm{mg} / \mathrm{l}$ ART exhibited upregulated expression of claudin-1, increased adhesive force (from $2,400 \pm 300$ to $3,600 \pm 500 \mathrm{pN}$ ), increased high connection among SHG44 cells, increased cytomembrane roughness (from $0.118 \pm 0.011$ to $0.269 \pm 0.015 \mu \mathrm{m}$ ) and reduced elasticity (from $23 \pm 8$ to $3.5 \pm 1.1 \mathrm{MPa}$ ). The present study demonstrated that ART could alter the biomechanical properties of the glioma cells to inhibit cell proliferation, migration and invasion.

\section{Introduction}

Glioma is the most common malignant tumor of the neural epithelium (1). Due to the progress of comprehensive treatments, the survival rate of glioma has recently increased. However, the relapse rate is still almost $100 \%$ within 2 years and the prognosis of this malignant disease remains poor (2). Current cancer treatments are based on chemotherapy, radiation therapy and surgery. However, the severe side-effects of chemotherapy and drug resistance are unresolved problems which still exist in clinical oncology and decrease successful therapeutic outcomes of chemotherapy $(3,4)$. Therefore, comprehensive studies on the mechanisms of this type of cancer and the identification of improved novel anticancer compounds are urgently needed.

Artesunate (ART) is an effective and safe anti-malarial drug which is extracted from the Chinese herb Artemisia annua (5). Previous studies have reported that ART is active against 
different types of cancer cells, and proliferation analysis indicated that $>70$ cell lines from different tumors were inhibited by ART (6-13). A previously published study indicated that esophageal squamous cell carcinoma could be resisted by ART by changing the cytoskeleton (14).

However, the effects of ART on glioma cell biomechanical properties which could influence the growth, apoptosis, migration and invasion have not yet been reported.

Atomic force microscopy (AFM) has become a powerful tool in the biological field for decades, and is a tool to obtain high-resolution ultrastructural data from the cellular membrane (15), and explore the shape and biomechanical properties of a single cell or cell cluster $(16,17)$. AFM has been frequently used to detect tumor cell membranes and biomechanical properties in the context of anticancer drugs (18-20).

The effects of ART on glioma cell behavior and the change in mechanical properties require investigation.

In the present study, the effects of ART on the change in glioma cell behaviors in regards to biomechanical properties were evaluated by AFM. In addition, the abnormal expression of the gene claudin-1, responsible for the tight junction disruption in cancer and associated with cell migration and invasion (21), was detected after treatment with ART in glioma cells.

\section{Materials and methods}

Cell culture conditions. Human glioma cell line SHG44, purchased from the Institute of Biochemistry and Cell Biology, Chinese Academy of Science (Shanghai, China), was grown in Dulbecco's modified Eagle's medium:nutrient mixture F-12, (DMEM/F12) (Gibco, Carlsbad, CA, USA) supplemented with $10 \%$ fetal bovine serum (FBS) (Invitrogen, Carlsbad, CA, USA) and incubated in a humidified atmosphere at $37^{\circ} \mathrm{C}$ with $5 \% \mathrm{CO}_{2}$. The cells were subcultured every 2 days.

MTT assay. The 3-(4,5-dimethyl-2-thiazolyl)-2,5-diphenyl2-H-tetrazolium bromide (MTT) assay, purchased from Sigma Corporation (St. Louis, MO, USA) was used to assess SHG44 cell proliferation after treatment with different concentrations of ART (Guilin Pharmaceutical Co., Ltd., Guangxi, China). In brief, SHG44 cells were seeded into a 96-well plate (Corning, Inc., New York, NY, USA) at a density of $5 \times 10^{3}$ cells/well. Then, different concentrations of ART $(0,10,30$ and $50 \mathrm{mg} / \mathrm{l})$ were added to the SHG44 cells for a final volume of $200 \mu \mathrm{l} /$ well. SHG44 cell proliferation was measured at 3 time points, 24, 36 and $48 \mathrm{~h}$. After incubation, $20 \mu \mathrm{l}$ of MTT $(5 \mathrm{mg} / \mathrm{ml})$ was added into each well, and the cells were incubated at $37^{\circ} \mathrm{C}$ for $4 \mathrm{~h}$. Then, the medium was removed from each well mentioned above and $200 \mu \mathrm{l}$ dimethyl sulfoxide (DMSO; Sigma Corporation) was added into each well. The optical density (OD) was determined at $490 \mathrm{~nm}$ with a microplate reader (Bio-Rad 550; 94547; Bio-Rad, Hercules, CA, USA). Each assay was run in triplicate.

Cell apoptosis assay by flow cytometry. Compared with the control group ( $0 \mathrm{mg} / \mathrm{l} \mathrm{ART})$, the optimal concentration of ART (30 $\mathrm{mg} / \mathrm{l}$, based on the results of MTT assay) was used, and the apoptosis rate of the SHG44 cells was assessed. Briefly, after being cultured with ART for 48 h, SHG44 cells were collected
Table I. RT-PCR primer sequences used for the amplification of specific genes.

\begin{tabular}{|c|c|c|c|}
\hline Genes & Primer sequence ( $\left.5^{\prime}-3^{\prime}\right)$ & $\begin{array}{l}\text { Product } \\
\text { size } \\
\text { (bp) }\end{array}$ & $\begin{array}{c}\text { Annealing } \\
\text { temp. } \\
\left({ }^{\circ} \mathrm{C}\right)\end{array}$ \\
\hline $\begin{array}{l}\text { GAPDH } \\
(22)\end{array}$ & $\begin{array}{l}\text { F TTCGTACCTGGCATTGACTGG } \\
\text { R GAAGGTGAAGGTCGGAGT }\end{array}$ & 225 & 57 \\
\hline $\begin{array}{l}\text { Claudin-1 } \\
\text { (22) }\end{array}$ & $\begin{array}{l}\text { F GATGAGGTGCAGAAGATGAGG } \\
\text { R AGAAGGCAGAGAGAAGCAGC }\end{array}$ & 200 & 63 \\
\hline
\end{tabular}

F, forward; R, reverse; temp, temperature.

at a density of $1 \times 10^{6} / \mathrm{ml}$, and washed 2 times with phosphatebuffered saline (PBS). For the apoptosis assay, the cells was suspended in $500 \mu \mathrm{l}$ of binding buffer. Then, $5 \mu \mathrm{l}$ of Annexin V and $5 \mu \mathrm{l}$ of propidium iodide (PI) (both from Nanjing KeyGen Biotech Co., Ltd., Nanjing, China) were added to each sample for $15 \mathrm{~min}$ in the dark. Finally, the cells were analyzed using BD FACSCalibur flow cytometry with CellQuest software (version 5.1; BD Biosciences, Franklin Lakes, NJ, USA). Each sample was repeated 3 times.

Cell migration and invasion assays. SHG44 cells were grown to $85 \%$ confluency in $25 \mathrm{~cm}^{2}$ culture flasks (Corning, Inc.) and treated with different concentrations of ART $(0,30 \mathrm{mg} / \mathrm{l})$ for $48 \mathrm{~h}$. For the migration assays, $1 \times 10^{5}$ live cells in serum-free media were seeded onto an inserted chamber $(8 \mu \mathrm{m}$; Corning, Inc.) not coated with Matrigel. The lower chamber contained culture media with $10 \%$ FBS. Twenty-four hours later, invasive cells were stained by crystal violet (Sigma-Aldrich, St. Louis, MO, USA) and counted under a microscope (IX71; Olympus, Tokyo, Japan). Experiments were repeated 3 times. For the invasion assays, experiments were carried out with Matrigel basement membrane matrix (BD Biosciences)-coated Transwell migration chambers; the other steps were the same as the migration assays.

Atomic force microscopy (AFM) analysis. The 3D morphology and biomechanical properties of the SHG44 cells treated with ART $(0,30 \mathrm{mg} / \mathrm{l})$ were detected by AFM. AFM was performed using protocols as previously described (14).

Analysis of claudin-1 expression. Transcriptase-polymerase chain reaction (PCR) and western blotting were performed to detect claudin-1 expression with specific primers and antibodies. We started reverse transcriptase-polymerase chain reaction (RT-PCR) with cell RNA. Then, we performed PCR with cDNA from cell RNA. Each PCR product $(10 \mu \mathrm{l})$ was electrophoresed on $1.5 \%$ agarose gels containing $0.5 \mathrm{mg} / \mathrm{ml}$ ethidium bromide. The primer sequences used for the amplification of specific genes are provided in Table I. Western blotting was used to detect claudin-1 expression at the protein level. The protein extracted from the control and $30 \mathrm{mg} / \mathrm{l}$ ART groups was run on and extracted from an SDS-PAGE gel. The corresponding claudin-1 primary antibody (Santa Cruz Biotechnology, Santa Cruz, CA, USA) was incubated in $10 \%$ 


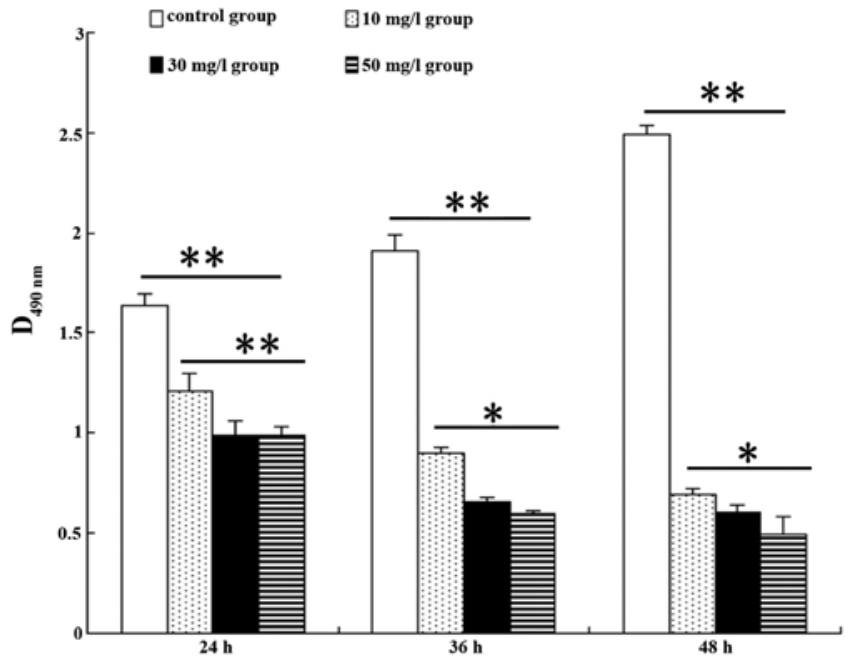

Figure 1. Proliferation of the SHG44 cells treated with different concentrations of ART. SHG44 cells were treated with ART for 24,36 and $48 \mathrm{~h}$. The proliferation level of the control group was significantly higher than that of the ART-treated groups; and that of the $10 \mathrm{mg} / \mathrm{l}$ ART group was significantly higher than that of the 30 and $50 \mathrm{mg} / 1$ ART groups. All data are presented as the mean \pm standard deviation; ${ }^{*} \mathrm{P}<0.05,{ }^{* *} \mathrm{P}<0.01$. ART, artesunate.

BSA/PBST. Western blotting was performed using standard protocols as previously described (22). The results of agarose gel electrophores were detected by gray scale analysis with software ImageJ [National Institutes of Health (NHI)].

Statistical analysis. The mechanical properties of the SHG44 cells were subjected to an arcsine transformation. The transformed data were then analyzed by analysis of variance (ANOVA; General Linear Model; SPSS 11.0) (SPSS, Inc., Chicago, IL, USA) (23).

For the analysis of other data, the data were also subjected to arcsine transformation and analyzed by either the Student's $\mathrm{t}$-test (the cell apoptosis rate and the results of cell migration/
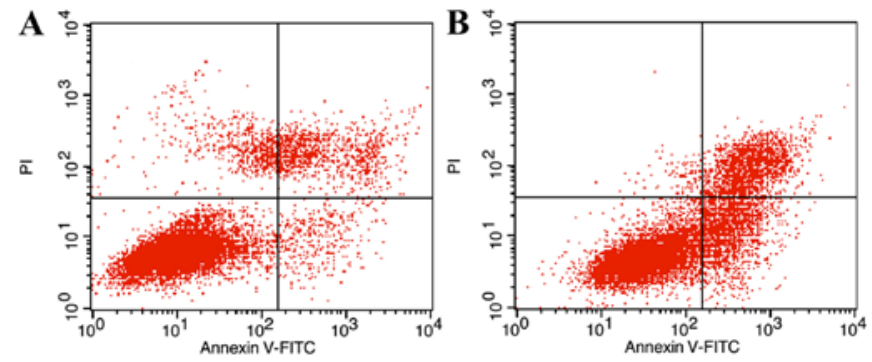

Figure 2. Cell apoptosis analysis. Cell apoptosis analysis of the (A) control and (B) $30 \mathrm{mg} / \mathrm{l} \mathrm{ART-treated} \mathrm{SHG44} \mathrm{cell} \mathrm{group.} \mathrm{ART,} \mathrm{artesunate.}$

invasion) or ANOVA (MTT analysis). $\mathrm{P}<0.05$ was considered to indicate a statistically significant result. All data are expressed as mean \pm standard deviation (SD).

\section{Results}

Effects of ART on cell growth and apoptosis in glioma cells. The proliferation of the SHG44 cells incubated with different concentrations of ART $(10,30$ and $50 \mathrm{mg} / \mathrm{l})$ was significantly reduced than that noted in the control SHG44 cells $(0 \mathrm{mg} / \mathrm{l}$ ART-treated) at 3 time points (Fig. 1). In addition, the proliferation levels of the 30 and $50 \mathrm{mg} / \mathrm{l}$ ART-treated groups were significantly lower than that of the $10 \mathrm{mg} / \mathrm{l}$ ART-treated group at all time points. However, there was no significant difference between the 30 and $50 \mathrm{mg} / \mathrm{l}$ ART-treated groups in regards to cell proliferation at all time points (Fig. 1). The growth of the SHG44 cells was markedly inhibited by ART in a time- and dose-dependent manner.

Based on the results of the cell proliferation assay, the optimal concentration of ART $(30 \mathrm{mg} / \mathrm{l})$ was used to treat the SHG44 cells for $48 \mathrm{~h}$ and the cell apoptosis rates were assessed. The results showed that the apoptosis rate of the $30 \mathrm{mg} / \mathrm{l}$ ART-treated group was significantly
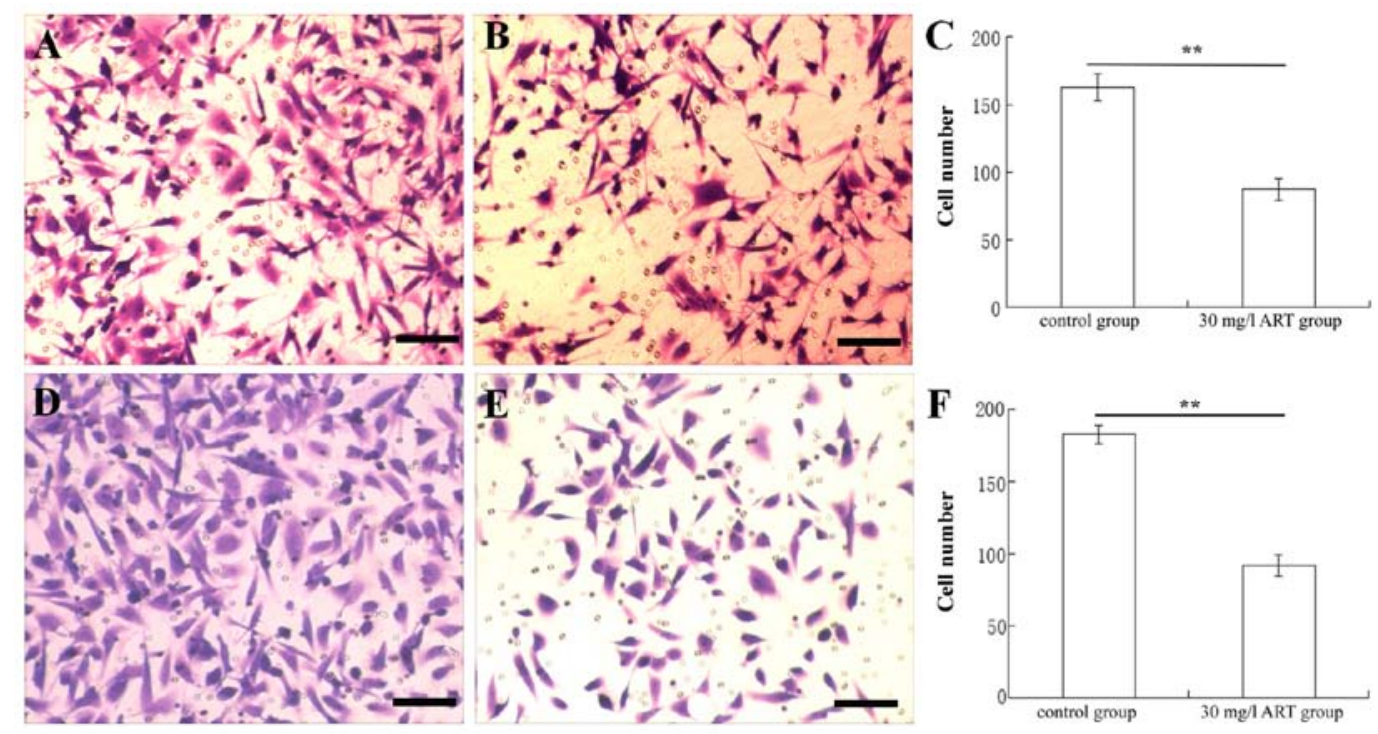

Figure 3. Transwell migration and invasion assays of the SHG44 cells following treatment with ART for $24 \mathrm{~h}$. Migration of the (A) control and (B) $30 \mathrm{mg} / \mathrm{l}$ ART-treated groups. (C) Statistical analysis of migration. Invasion of the (D) control and (E) $30 \mathrm{mg} / \mathrm{l}$ ART-treated groups. (F) Statistical analysis of invasion. The relative ratio of invasive cells/field is presented. Bar, $100 \mu \mathrm{m}$. All data are presented as the mean \pm standard deviation; ** P<0.01. ART, artesunate. 


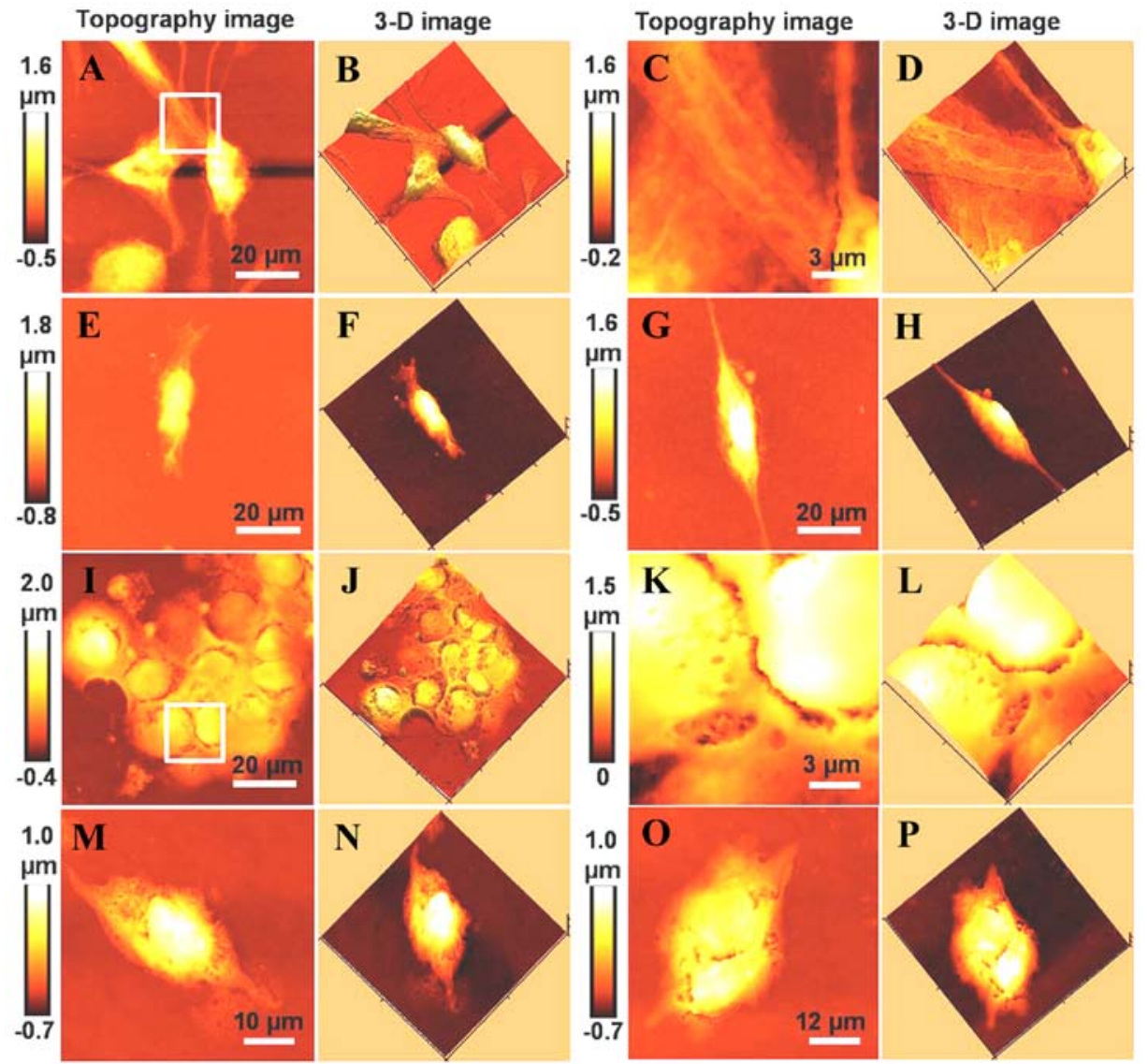

Figure 4. AFM images of SHG44 cell connections. (A) 2D and (B) 3D AFM images of SHG44 cell clusters cultured in vitro for $48 \mathrm{~h}$ without ART treatment. (C) 2D and (D) 3D ultra-structure AFM images of cell connection in A. (E and G) 2D and (F and H) 3D AFM images of a single SHG44 cell. (I) 2D and (J) 3D AFM images of SHG44 cell cluster cultured in vitro for $48 \mathrm{~h}$ following treatment with $30 \mathrm{mg} / 1 \mathrm{ART}$. (K) 2D and (L) 3D ultra-structure AFM images of cell connection in I. (M and O) 2D and (N and P) 3D AFM image of a single SHG44 cell treated with $30 \mathrm{mg} / \mathrm{l}$ ART. The connections among SHG44 cell clusters without ART treatment were loose (A-D). The morphology of SHG44 indicated they were slender spindle or polygon in nature (E-H). However, the connection among SHG44 cell clusters treated with $30 \mathrm{mg} / \mathrm{l}$ ART cultured in vitro for $48 \mathrm{~h}$ was very tight (I-L). The morphology of the SHG44 cells treated with $30 \mathrm{mg} / \mathrm{l}$ ART changed from a slender spindle/polygon to a wide oval shape (M-P).

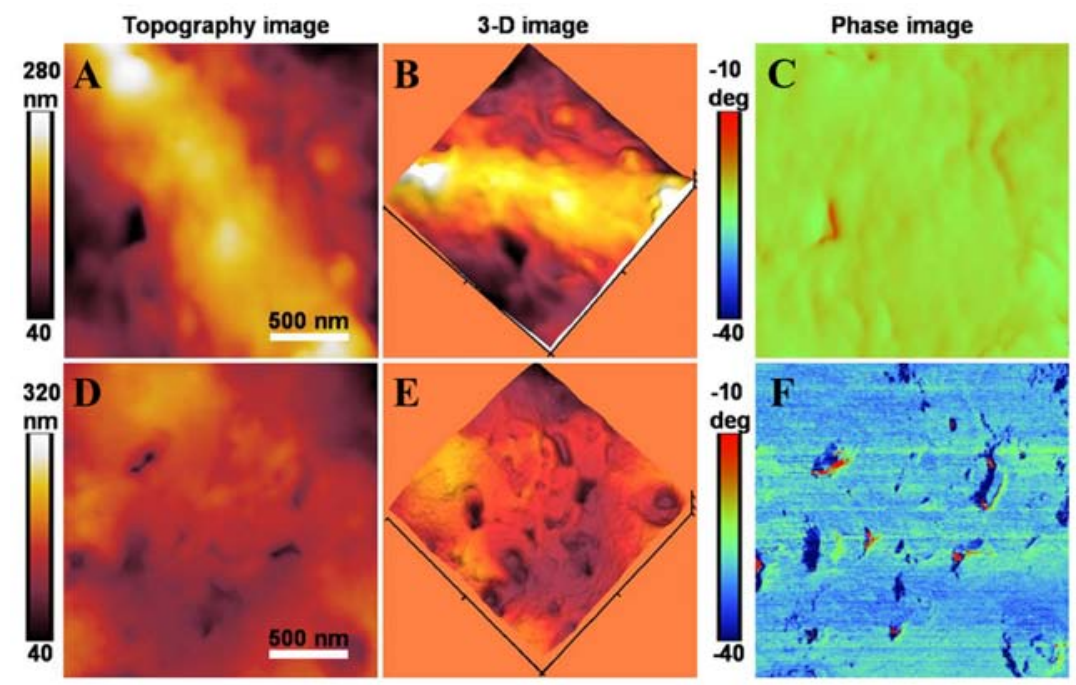

Figure 5. Ultra-structure of SHG44 cells. (A) Topography and (B) 3D images of an untreated SHG44 cell membrane nano-structure which exhibits a smooth membrane (C). (D) Topography and (E) 3D images of an SHG44 cell membrane nano-structure treated with $30 \mathrm{mg} / \mathrm{l}$ ART which exhibits a more uneven membrane compared with $\mathrm{C}(\mathrm{F})$.

increased $(23.7 \pm 4.16 \%)$ compared with the control group $(6.88 \pm 0.062 \%)$ (Fig. 2A and B).
ART inhibits the migration and invasion of glioma cells. Transwell assay was used to analyze the migration and inva- 
Table II. Biomechanical properties of the SHG44 cells after treatment with ART.

\begin{tabular}{lccc}
\hline & $\begin{array}{c}\text { Ra of cyto- } \\
\text { membrane } \\
(\mu \mathrm{m})\end{array}$ & $\begin{array}{c}\text { Adhesive force } \\
(\mathrm{pN})\end{array}$ & $\begin{array}{c}\text { Elasticity } \\
(\mathrm{MPa})\end{array}$ \\
\hline $\begin{array}{l}\text { Control group } \\
(0 \mathrm{mg} / \mathrm{l} \text { ART })\end{array}$ & $0.118 \pm 0.011^{\mathrm{b}}$ & $2,400 \pm 300^{\mathrm{b}}$ & $23 \pm 8^{\mathrm{a}}$ \\
$30 \mathrm{mg} /$ group & $0.269 \pm 0.015^{\mathrm{a}}$ & $3,600 \pm 500^{\mathrm{a}}$ & $3.5 \pm 1.1^{\mathrm{b}}$ \\
\hline
\end{tabular}

aP $<0.05$ vs. the control group. $\mathrm{pN}=10^{-12}$ Newtons; $\mathrm{MPa}=10^{6} \mathrm{Pascals}$. ART, artesunate; Ra, average roughness.

sion of the SHG44 cells following treatment with ART. After incubation with $30 \mathrm{mg} / \mathrm{l} \mathrm{ART}$, the migration and invasion of the SHG44 cells were obviously inhibited (Fig. 3). The migration and invasion abilities of the control group were significantly enhanced when compared with these abilities in the $30 \mathrm{mg} / \mathrm{l}$ ART-treated group. These results indicate that ART reduced the cell migration and invasion of glioma cells in vitro.

Biomechanical properties of SHG44 cells treated with ART are significantly altered as detected by AFM. Different cell types or cells in different physiological conditions possess a unique structure with specific mechanical properties. In the present study, AFM was used to detect changes in the morphology and biomechanical properties of SHG44 cells incubated with ART. Fig. 4 demonstrates without ART treatment, the connection among the SHG44 cell clusters was loose (Fig. 4A-D); but the connection among the SHG44 cell cluster following treatment with $30 \mathrm{mg} / \mathrm{l}$ ART cultured in vitro for $48 \mathrm{~h}$ was extremely tight (Fig. 4I-L); and the SHG44 cells exhibited a slender spindle or polygon morphology (Fig. 4E-H); the SHG44 cells treated with $30 \mathrm{mg} / \mathrm{l}$ ART were wide oval in shape (Fig. 4M-P).
The roughness of the membrane ultra-structures of the control group cells (Fig. 5A-C) was smoother than that of the $30 \mathrm{mg} / \mathrm{l}$ ART-treated group (Fig. 5D-F; Table II). The cell membrane of the $30 \mathrm{mg} / \mathrm{l}$ ART-treated group was more uneven and irregular.

In the SHG44 control group (without ART treatment), the adhesive force was $2,400 \pm 300 \mathrm{pN}$ (Fig. $6 \mathrm{~A}$ and B); the elasticity force was $23 \pm 8 \mathrm{MPa}$ (Fig. $6 \mathrm{C}$ and D); and the average roughness (Ra) was $0.118 \pm 0.011 \mu \mathrm{m}$. Following treatment with ART at $30 \mathrm{mg} / 1$ in the SHG44 cells, the adhesive force was $3,600 \pm 500 \mathrm{pN}$ (Fig. $6 \mathrm{E}$ and F); the elasticity force was $3.5 \pm 1.1 \mathrm{MPa}$ (Fig. 6G and H); and the Ra was $0.269 \pm 0.015 \mu \mathrm{m}$. Compared with the SHG44 control group, the adhesive force and $\mathrm{Ra}$ of the $30 \mathrm{mg} / \mathrm{l}$ ART-treated group were significantly higher, whereas the elasticity force of the $30 \mathrm{mg} / \mathrm{l}$ ART-treated group was significantly lower than that of the control SHG44 cells (Table II).

ART promotes expression of claudin-1 in glioma. The expression of claudin-1 was significantly higher than that of the control group after treatment with $30 \mathrm{mg} / \mathrm{l} \mathrm{ART}$, at the molecular and protein levels (Fig. 7).

\section{Discussion}

The incidence and mortality of human glioma are high worldwide, and the treatment outcome is poor. ART is widely used as an effective drug to treat malaria (3-6). Previously, studies have reported that ART decreases tumorigenesis and has low toxicity, and can also pass through the blood-brain barrier. This indicates that ART could be a new potential anti-glioma drug (10-13). In the present study, we detected the effects of the anti-malarial agent ART on SHG44 cells. After being treated with ART, the Ra of the cell membrane, apoptosis rate and the expression of claudin-1 in addition to the adhesive force were significantly increased. Whereas the elasticity of SHG44 cells was significantly decreased after incubation with ART.

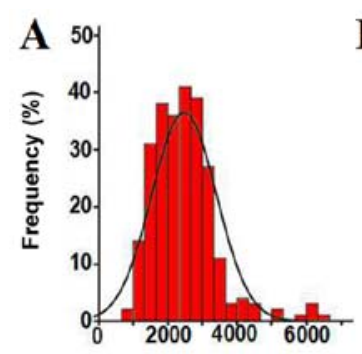

B
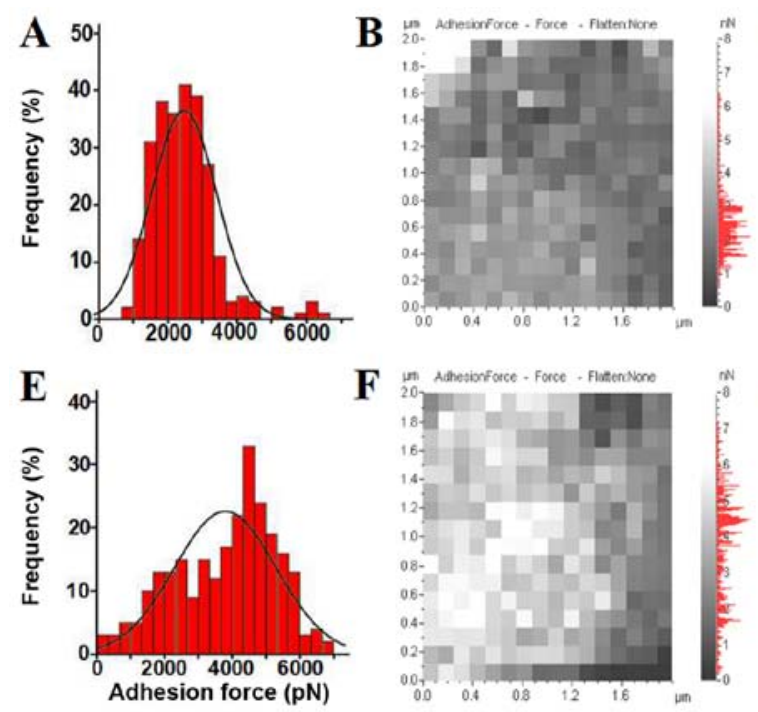
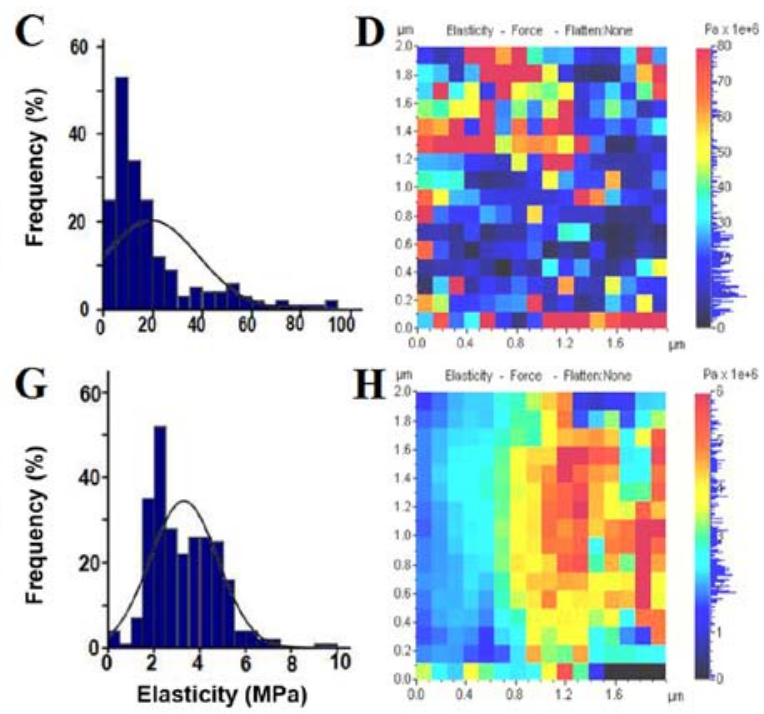

Figure 6. AFM force-distance curve analyses detect adhesive force and elasticity of the SHG44 cells. (A-D) Control group, SHG44 cells without ART treatment: (A) adhesion force histogram ( $\mathrm{n}=256)$; (B) adhesion force map of the same cell surface area; (C) elasticity histogram ( $\mathrm{n}=256$ ); and (D) elasticity map of the same cell surface area. (E-H) SHG44 cells with $30 \mathrm{mg} / \mathrm{l}$ ART-treatment for $48 \mathrm{~h}$ : (E) adhesion force histogram (n=256); (F) adhesion force map of the same cell surface area; $(\mathrm{G})$ elasticity histogram $(\mathrm{n}=256)$; and $(\mathrm{H})$ elasticity map of the same cell surface area. 
A
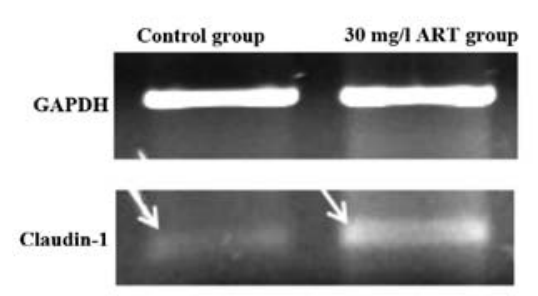

B

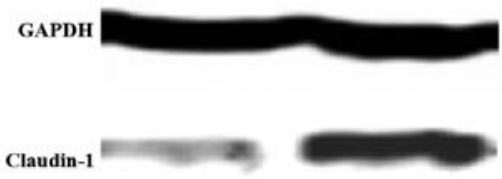

C

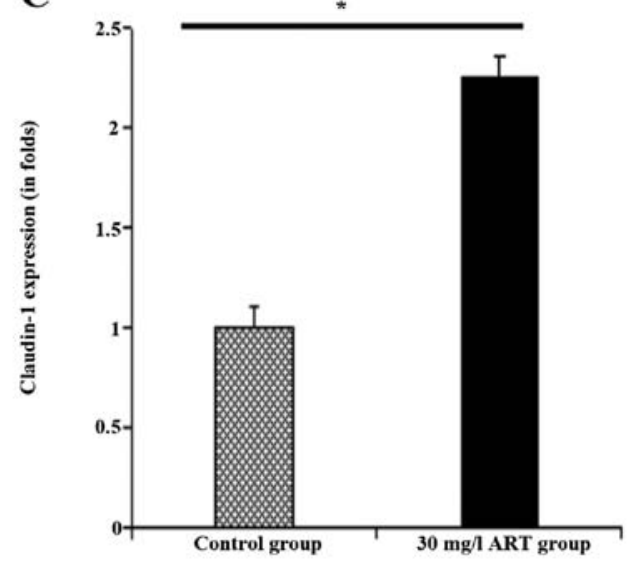

Figure 7. Expression of claudin-1 in human glioma tumor cells treated with different concentrations of ART. After treatment with 30 mg/l ART, the expression of claudin-1 in glioma was significantly higher than that of the control group. (A) Electrophoresed results of claudin-1 expression. (B) Western blot results of claudin-1 expression. (C) Histogram of gray scale analysis of claudin-1 expression levels (based on electrophoresed results). Claudin-1 expression values are represented as mean \pm standard deviation, ${ }^{*} \mathrm{P}<0.05$. ART, artesunate.

The surface of the cell membrane contains numerous different biological macromolecules, including phospholipids, transmembrane and adsorbed glycoproteins, galactose and glucose as exchange interfaces to transfer signals from outside to inside, which are important to maintain the functionality and integrity of the cell membrane $(24,25)$. Changes in the surface of the cell membrane may affect the integrity of the cell membrane and signal transportation can therefore directly influence cell activities and the cytoskeleton $(26,27)$.

The cytoskeleton could determine the cellular morphology and biomechanical characteristics during different physiological periods (28). A previous study reported that chromosome stability and cell proliferation could be influenced by altered cytoskeleton (29).

Apoptosis is important to maintain normal cell homeostasis, and dysfunction of apoptosis is common in cancer cells (30). The stability of the cytoskeleton is important to maintain cell structural integrity and functionality, which could affect cell apoptosis, and has been studied as a possible target for anticancer therapy; thus, cytoskeleton damage could promote apoptosis (31).

The results of the cell apoptosis analysis and AFM detection indicated that ART may inhibit the proliferation and promote the apoptosis of SHG44 cells by changing the cell membrane-surface integrity, halting signal transfer and affecting the cytoskeleton stability of SHG44 cells.

Tight junctions are necessary for endothelial and epithelial cells, which are formed by the essential protein claudin family (32). Damage of tight junctions could cause increased invasiveness, the loss of cohesion and deletion of differentiation, which promotes tumorigenesis in epithelial cells. The abnormal expression of the claudin family was identified to be responsible for tight junction disruption in cancer (21). Previously published studies indicate that increased claudin-1 expression was found to confer cell death in nasopharyngeal cancers (33), and claudin-1 expression was significantly associated with basal-like breast cancer (34). In glioma, downregulated levels of claudin-1 are associated with progression of the grade of malignancy, and claudin-1 expression is significantly lower in glioma than that in normal cells (22).

Cell elasticity plays a role in tumor cell migration and invasion (35), and may reflect cytoskeleton alterations and may be associated with cell deformation (36).

Claudin-1 gene expression and AFM detection indicated that ART may inhibit the migration and invasion of SHG44 cells by increasing the expression of claudin-1 which may strengthen adhesive force, and cell cluster connections and may suppress cell elasticity.

In the present study, ART was found to have the potential ability to inhibit the proliferation, migration and invasion of glioma cells by affecting the expression of claudin-1 gene, cell morphology and structure. Thus, ART may be a potential new drug for glioma.

\section{Acknowledgements}

The present study was supported by the Natural Science Foundation of Shanxi (grant no. 2015011095) to S.L., the Doctoral Start up Research Fund of Shanxi Medical University (grant no. 03201006) to R.S., the Science and Technology Innovation Fund of Shanxi Medical University (grant no. 01201309) to R.S., and the Youth Research Fund of Shanxi Medical University (grant no. Q02201202) to R.S.

\section{References}

1. Louis DN: Molecular pathology of malignant gliomas. Annu Rev Pathol 1: 97-117, 2006.

2. Saika K and Katanoda K: Comparison of time trends in brain and central nervous system cancer mortality (1990-2006) between countries based on the WHO mortality database. Jpn J Clin Oncol 41: 304-305, 2011.

3. Sørensen MD, Fosmark S, Hellwege S, Beier D, Kristensen BW and Beier CP: Chemoresistance and chemotherapy targeting stem-like cells in malignant glioma. Adv Exp Med Biol 853: 111-138, 2015.

4. Katsetos CD, Reginato MJ, Baas PW, D'Agostino L, Legido A, Tuszyn Ski JA, Dráberová E and Dráber P: Emerging microtubule targets in glioma therapy. Semin Pediatr Neurol 22: 49-72, 2015. 
5. White NJ: Qinghaosu (artemisinin): The price of success. Science 320: 330-334, 2008.

6. Youns M, Efferth T, Reichling J, Fellenberg K, Bauer A and Hoheisel JD: Gene expression profiling identifies novel key players involved in the cytotoxic effect of Artesunate on pancreatic cancer cells. Biochem Pharmacol 78: 273-283, 2009.

7. Hou J, Wang D, Zhang R and Wang H: Experimental therapy of hepatoma with artemisinin and its derivatives: In vitro and in vivo activity, chemosensitization, and mechanisms of action. Clin Cancer Res 14: 5519-5530, 2008.

8. Li LN, Zhang HD, Yuan SJ, Yang DX, Wang L and Sun ZX Differential sensitivity of colorectal cancer cell lines to artesunate is associated with expression of beta-catenin and E-cadherin. Eur J Pharmacol 588: 1-8, 2008.

9. Nam W, Tak J, Ryu JK, Jung M, Yook JI, Kim HJ and Cha IH: Effects of artemisinin and its derivatives on growth inhibition and apoptosis of oral cancer cells. Head Neck 29: 335-340, 2007

10. Liu WM, Gravett AM and Dalgleish AG: The antimalarial agent artesunate possesses anticancer properties that can be enhanced by combination strategies. Int J Cancer 128: 1471-1480, 2011.

11. Rinner B, Siegl V, Pürstner P, Efferth T, Brem B, Greger H and Pfragner R: Activity of novel plant extracts against medullary thyroid carcinoma cells. Anticancer Res 24: 495-500, 2004.

12. Efferth T, Dunstan H, Sauerbrey A, Miyachi H and Chitambar CR The anti-malarial artesunate is also active against cancer. Int J Oncol 18: 767-773, 2001.

13. Efferth T, Sauerbrey A, Olbrich A, Gebhart E, Rauch P, Weber HO, Hengstler JG, Halatsch ME, Volm M, Tew KD, et al: Molecular modes of action of artesunate in tumor cell lines. Mol Pharmacol 64: 382-394, 2003.

14. Shi R, Cui H, Bi Y, Huang X, Song B, Cheng C, Zhang L, Liu J, He C, Wang F, et al: Artesunate altered cellular mechanical properties leading to deregulation of cell proliferation and migration in esophageal squamous cell carcinoma. Oncol Lett 9 : $2249-2255,2015$

15. Hörber JK and Miles MJ: Scanning probe evolution in biology. Science 302: 1002-1005, 2003.

16. Alonso JL and Goldmann WH: Feeling the forces: Atomic force microscopy in cell biology. Life Sci 72: 2553-2560, 2003

17. Lesniewska E, Milhiet PE, Giocondi MC and Le Grimellec C: Atomic force microscope imaging of cells and membranes. Methods Cell Biol 68: 51-65, 2002.

18. Soofi SS, Last JA, Liliensiek SJ, Nealey PF and Murphy CJ: The elastic modulus of Matrigel as determined by atomic force microscopy. J Struct Biol 167: 216-219, 2009.

19. Kondra S, Laishram J, Ban J, Migliorini E, Di Foggia V, Lazzarino M, Torre V and Ruaro ME: Integration of confocal and atomic force microscopy images. J Neurosci Methods 177: 94-107, 2009

20. Wang J, Wan Z, Liu W, Li L, Ren L, Wang X, Sun P, Ren L, Zhao H, Tu Q, et al: Atomic force microscope study of tumor cell membranes following treatment with anti-cancer drugs. Biosens Bioelectron 25: 721-727, 2009.
21. D'Souza T, Agarwal R and Morin PJ: Phosphorylation of claudin-3 at threonine 192 by cAMP-dependent protein kinase regulates tight junction barrier function in ovarian cancer cells. J Biol Chem 280: 26233-26240, 2005.

22. Karnati HK, Panigrahi M, Shaik NA, Greig NH, Bagadi SA, Kamal MA and Kapalavayi N: Down regulated expression of claudin- 1 and claudin-5 and up regulation of $\beta$-catenin: Association with human glioma progression. CNS Neurol Disord Drug Targets 13: 1413-1426, 2014.

23. Snedecor GW and Cochran WG: Statistical Methods. 7th edition. Iowa State University Press, Ames, IA, USA, pp32-43, 1980.

24. Puech PH, Poole K, Knebel D and Muller DJ: A new technical approach to quantify cell-cell adhesion forces by AFM. Ultramicroscopy 106: 637-644, 2006.

25. Geiger B, Bershadsky A, Pankov R and Yamada KM: Transmembrane crosstalk between the extracellular matrix - cytoskeleton crosstalk. Nat Rev Mol Cell Biol 2: 793-805, 2001.

26. Sato K, Adachi T, Ueda D, Hojo M and Tomita Y: Measurement of local strain on cell membrane at initiation point of calcium signaling response to applied mechanical stimulus in osteoblastic cells. J Biomech 40: 1246-1255, 2007.

27. Voïtchovsky K, Antoranz Contera S, Kamihira M, Watts A and Ryan JF: Differential stiffness and lipid mobility in the leaflets of purple membranes. Biophys J 90: 2075-2085, 2006.

28. Fuchs E and Cleveland DW: A structural scaffolding of intermediate filaments in health and disease. Science 279: 514-519, 1998.

29. Saunders WS, Shuster M, Huang X, Gharaibeh B, Enyenihi AH, Petersen I and Gollin SM: Chromosomal instability and cytoskeletal defects in oral cancer cells. Proc Natl Acad Sci USA 97: 303-308, 2000

30. Mahoney JA and Rosen A: Apoptosis and autoimmunity. Curr Opin Immunol 17: 583-588, 2005.

31. Gourlay CW and Ayscough KR: A role for actin in aging and apoptosis. Biochem Soc Trans 33: 1260-1264, 2005.

32. Hadj-Rabia S, Baala L, Vabres P, Hamel-Teillac D, Jacquemin E, Fabre M, Lyonnet S, De Prost Y, Munnich A, Hadchouel M, et al: Claudin-1 gene mutations in neonatal sclerosing cholangitis associated with ichthyosis: A tight junction disease. Gastroenterology 127: 1386-1390, 2004

33. Lee JW, Hsiao WT, Chen HY, Hsu LP, Chen PR, Lin MD, Chiu SJ, Shih WL and Hsu YC: Upregulated claudin-1 expression confers resistance to cell death of nasopharyngeal carcinoma cells. Int J Cancer 126: 1353-1366, 2010

34. Blanchard AA, Ma X, Dueck KJ, Penner C, Cooper SC, Mulhall D, Murphy LC, Leygue E and Myal Y: Claudin 1 expression in basal-like breast cancer is related to patient age. BMC Cancer 13: 268, 2013.

35. Kumar S and Weaver VM: Mechanics, malignancy, and metastasis: The force journey of a tumor cell. Cancer Metastasis Rev 28: 113-127, 2009.

36. Fletcher DA and Mullins RD: Cell mechanics and the cytoskeleton. Nature 463: 485-492, 2010. 